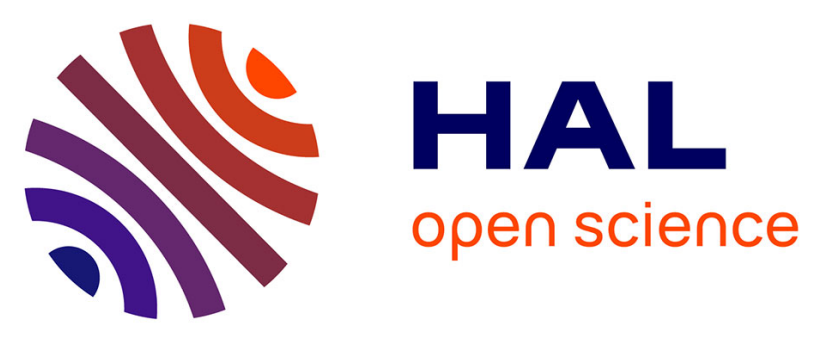

\title{
Soil temperature synchronisation improves representation of diel variability of ecosystem respiration in Sphagnum peatlands
}

Benoît D'angelo, Sébastien Gogo, Fatima Laggoun-Défarge, Franck Le Moing,

Fabrice Jégou, Christophe Guimbaud

\section{To cite this version:}

Benoît D'angelo, Sébastien Gogo, Fatima Laggoun-Défarge, Franck Le Moing, Fabrice Jégou, et al.. Soil temperature synchronisation improves representation of diel variability of ecosystem respiration in Sphagnum peatlands. Agricultural and Forest Meteorology, 2016, 223, pp.95-102. 10.1016/j.agrformet.2016.03.021 . insu-01303659

\section{HAL Id: insu-01303659}

https://hal-insu.archives-ouvertes.fr/insu-01303659

Submitted on 18 Apr 2016

HAL is a multi-disciplinary open access archive for the deposit and dissemination of scientific research documents, whether they are published or not. The documents may come from teaching and research institutions in France or abroad, or from public or private research centers.
L'archive ouverte pluridisciplinaire HAL, est destinée au dépôt et à la diffusion de documents scientifiques de niveau recherche, publiés ou non, émanant des établissements d'enseignement et de recherche français ou étrangers, des laboratoires publics ou privés.

\section{(1) (1) $\$$}

Distributed under a Creative Commons Attribution - NonCommercial - NoDerivatives 44.0 


\title{
Soil temperature synchronisation improves representation of diel variability of ecosystem respiration in Sphagnum peatlands
}

\author{
D’Angelo Benoît ${ }^{\mathrm{a}, \mathrm{b}, \mathrm{c}, \mathrm{d}, \mathrm{e}}$, Sébastien Gogo ${ }^{\mathrm{c}, \mathrm{d}, \mathrm{e}, *}$, Fatima Laggoun-Défarge ${ }^{\mathrm{c}, \mathrm{d}, \mathrm{e}}$, Franck \\ Le Moing $^{\text {c,d,e }}$, Fabrice Jégou ${ }^{\text {a,b }}$, Christophe Guimbaud ${ }^{\text {a,b }}$
}

${ }^{a}$ Université d'Orléans, LPC2E, UMR 7328, 45071 Orléans, France

${ }^{\mathrm{b}}$ CNRS, LPC2E, UMR 7328, 45071 Orléans, France

${ }^{\mathrm{c}}$ Université d'Orléans, ISTO, UMR 7327, 45071 Orléans, France

${ }^{\mathrm{d}}$ CNRS, ISTO, UMR 7327, 45071 Orléans, France

${ }^{\text {e }}$ BRGM, ISTO, UMR 7327, BP 36009, 45060 Orléans, France

* Corresponding author: benoit.dangelo@ cnrs-orleans.fr (0033 (0)2 384940 93)

\section{Abstract}

The temperature dependence of Ecosystem Respiration (ER) is often assessed based on the temperature of one specific layer. Air temperature or temperatures in the first ten centimetres of the soil profile are the most frequently used temperatures in models. However, previous studies showed that the relationship between ER and temperature is depth dependent, making depth selection for temperature measurements an important issue, especially at short time-scales. The present study explores one possible way to assess this relationship by synchronising the ER and temperature signals and to test if the relationship between ER and temperature differs between daytime and nighttime. To do so, ER measurements were undertaken in 2013 in four Sphagnum-peatlands across France using the closed chamber method. The ER fluxes were measured hourly during 72 hours in each of four replicates in each site. Synchronisations between ER and T signal were determined for each depth (from surface to $30 \mathrm{~cm}$ depth) by selecting the time-delay leading to the best correlation between ER and soil temperatures and ER was then modelled. Our results showed that: (i) the delay between ER and soil temperature is greater in peat than in mineral soils; (ii) at a daily time-scale synchronisation can improve the model representation using soil temperatures.

Keywords: $\mathrm{CO}_{2}, \mathrm{Q}_{10}$, chamber, temperature depth, time-delay 


\section{Introduction}

At a global scale, Ecosystem Respiration (ER) and photosynthesis are the largest carbon (C)

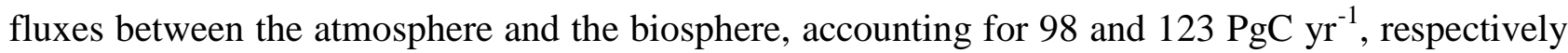
(Bond-Lamberty \& Thomson, 2010; Beer et al., 2010). By contrast the fossil fuel and cement production flux is one order of magnitude lower, at $7.8 \mathrm{PgC} \mathrm{yr}^{-1}$ (Ciais et al., 2014). Consequently, even small variations in the ecosystem fluxes may result in substantial changes in net $\mathrm{C}$ storage dynamics. This can have a significant effect on the global $\mathrm{C}$ budget, in particular on the atmospheric $\mathrm{C}$ concentration. The $\mathrm{C}$ stock in natural ecosystems is divided into two pools: vegetation, which contains 450 to $650 \mathrm{PgC}$, and the soil which contains 1500 to $2400 \mathrm{PgC}$ (Ciais et al., 2014; Carvalhais et al., 2014). Across the world, the soil organic C (SOC) pool is spatially heterogeneous in terms of source and physical conditions, leading to variable storage rates between ecosystem types. Peatlands are efficient $\mathrm{C}$ storage ecosystems. They cover only $3 \%$ of the global terrestrial area, but contain from 270 to $455 \mathrm{PgC}$ as $\mathrm{SOC}$, i.e. from 10 to $30 \%$ of the world's soil C (Gorham, 1991; Turunen et al., 2002; Limpens et al., 2008). Thus, peatlands are considered as a hot spots for SOC storage, and their evolution under current environmental changes deserves attention.

As in many other terrestrial ecosystems, many factors affect ER variability in peatlands: temperature, soil water content, vegetation, and substrate supply (Luo \& Zhou, 2006). All these factors are thought to be affected by global change, with unknown consequences on the $\mathrm{C}$ balance (Limpens et al., 2008). More specifically the temperature affect ER directly (biochemical reaction rates are related to temperature) and indirectly (vegetation, and particularly root growth, transport rates) (Luo \& Zhou, 2006) and is thus largely utilized to model ER. Different temperature may be used: either air (e.g., Bortoluzzi et al., 2006), or soil temperature. The most commonly used soil temperatures are those at $-5 \mathrm{~cm}$ (Ballantyne et al., 2014; Görres et al., 2014) and $-10 \mathrm{~cm}$ (Kim \& Verma, 1992; Zhu et al., 2015). In some studies, different depths are used and the selected one depends on the goodness-of-fit (Günther et al., 2014; Zhu et al., 2015). All these studies use the 
chamber method to measure gas fluxes and even though most studies use $-5 \mathrm{~cm}$ soil temperature, no clear consensus exists.

The relationship between ER and temperature is often described using the $\mathrm{Q}_{10}$ indicator, which represents the proportional increase of a reaction rate due to a $10^{\circ} \mathrm{C}$ rise in temperature. However, even if the $\mathrm{Q}_{10}$ seems coherent at a global scale (Mahecha et al., 2010), reported values show a significant variability at the ecosystem level (Graf et al., 2008). Because the calculated $\mathrm{Q}_{10}$ are not linked to a single reaction but to multiple processes, numerous issues arise (Davidson et al., 2006). Among them are the time-scale considered (Curiel Yuste et al., 2004), the depth (Graf et al., 2008) and the time-delays between ER and soil temperatures (Phillips et al., 2011).

More specifically Pavelka et al. (2007) and Graf et al. (2008) showed that the relationship between ER and temperature is depth dependent since heat transfer in the soil profile is not instantaneous and leads to a time-delay between the temperature and the ER signals. One way to deal with the time-delays might be to synchronise ER fluxes and temperature measurements according to Pavelka et al. (2007). Another issue is the difference between the daytime and nighttime ER relationship with temperature. Juszczak et al. (2012), for example, showed that there are significant differences between ER modelled with daytime and nighttime data. Assessing these differences may be important when working at a daily timescale and when treating data from eddycovariance measurements.

Based on these previous studies, we expected that time-delays in Sphagnum-dominated peatlands would be significant, even in the first 10 centimetres depth and that they would lead to a better description of observed data once taken into account, especially through data synchronisation. To our knowledge no studies have explored the time-delay between ER and soil temperature in peatlands yet. To test these predictions, ER fluxes, during the growing season in 4 Sphagnumdominated peatlands were measured in 2013. Continuous measurements over 72 hours were carried out in each site using static dark chambers. Air and soil temperature were also monitored. 
Specifically, the relationship between ER and temperature, measured at different depths in peat was studied.

The aim of this study was (i) to highlight any time-delay at the daily timescale between ER and soil temperature at different depths in peatlands (ii) to assess the effect of synchronisation between ER and temperature in the model representation of the diel ER variations.

\section{Material and methods}

\subsection{Study sites}

The study was performed on four French Sphagnum-dominated peatlands: Bernadouze (BDZ, Ariège; 3.75 ha, N 424809, E 1²524, 1400 m), Frasne (FRN, Doubs; 98 ha, N 464935, E 6¹020, 836 m), Landemarais (LDM, Ille-et-vilaine; 23 ha, N 48²630, E 1²1054, $154 \mathrm{~m}$ ), and La Guette (LGT, Cher; 26 ha, N 471944, E $2^{\circ} 1704,145 \mathrm{~m}$ ). Mean annual air temperatures and annual rainfalls were $6,7.5,11,11^{\circ} \mathrm{C}$, and $1700,1400,870,880 \mathrm{~mm}$ for BDZ, FRN, LDM and LGT respectively. During the measurements the water table level remained constant at to $-12,-7,-35$ and $-9 \mathrm{~cm}$ for BDZ, FRN, LDM and LGT.

\subsection{Data acquisition}

Fieldwork was conducted between July and October 2013. Four plots (replicates) with similar plant cover, were chosen at each site. For the most part the plant covers consist of Sphagnum spp. Four cylindrical PVC collars (diameter: $31 \mathrm{~cm}$, height: $15 \mathrm{~cm}$ ) were inserted into the peat the day before beginning the measurements. $\mathrm{CO}_{2}$ fluxes were measured in the 4 plots once an hour in random order for 72 hours. These measurements were undertaken using a closed static chamber (diameter of $30.5 \mathrm{~cm}$, height of $30 \mathrm{~cm}$ ), with a GMP343 Vaisala probe. ER was measured with a transparent chamber covered by an opaque material to avoid input of photosynthetically active 
radiation. Inside the chamber the air was homogenized with a fan in order to minimize concentration gradients (Pumpanen et al., 2004). Measurement lasted a maximum of 5 min with $\mathrm{CO}_{2}$ concentration recorded every 5 seconds as well as the relative humidity and the temperature inside the chamber.

At each site a weather station and a data logger were set up near the plots to provide meteorological and environmental data recorded every second: air relative humidity, solar radiation, peat temperature (at $-5,-10,-20$ and $-30 \mathrm{~cm}$ depth below soil surface) and surface air temperature. The latter temperature was measured at an altitude as close as possible to the top of the Sphagnum capitulum (considered as the zero), which considering the sensor and shelter size was about $15 \mathrm{~cm}$ above the Sphagnum capitulum. This temperature will be referred as the 0 depth in the figures.

After the 72 hours of measurements, at each site and for each replicate, one peat core $(30 \mathrm{~cm}$ height and $15 \mathrm{~cm}$ diameter) was extracted for physico-chemical characterisation. The results of these analyses are shown as supplementary materials.

\subsection{Data synchronisation}

For a specific depth time-serie, temperature averages were calculated for each ER measurement time and duration. The average temperatures were correlated with the ER. Then, the correlation was repeated with 10 minutes shifts in the temperature time-serie until a 24 hour shift (Figure 1), to take into account the effect of temperature heat transfer from surface to soil. The whole operation was repeated with each depth. Finally the synchronisation was determined for each depth, by selecting the time-delay corresponding to the highest correlation. Negative correlations caused by the phase shift were discarded.

\subsection{Sensitivity of ER to temperature}

Three widely used models Fang \& Moncrieff (2001) were implemented to study the 
relationship between ER and temperature: Linear regression (1), exponential models: $\mathrm{Q}_{10}(2)$ and Arrhenius (3)

$$
\begin{aligned}
& \mathrm{ER}=\alpha+\beta \mathrm{T} \\
& \mathrm{ER}=\alpha \exp (\beta \mathrm{T}) ; \mathrm{Q}_{10}=\exp (10 * \beta) \\
& \mathrm{ER}=\alpha \exp (-\beta / \mathrm{RT})
\end{aligned}
$$

ER was estimated using air temperature, soil temperatures at $-5,-10,-20$ and $-30 \mathrm{~cm}$ depth with both non-synchronised and synchronised datasets and using the mean of the replicates. $\alpha$ and $\beta$ are the fitted parameters, ER the Ecosystem Respiration, $\mathrm{T}$ the temperature at a given depth, $\mathrm{R}$ the ideal gas constant. In the Arrhenius equation, $\beta$ represent the activation energy. Calculations were implemented in R, and modelled data were adjusted to measured data using Ordinary Least Squares (OLS). The goodness-of-fit was estimated by calculating the regression coefficient $\left(\mathrm{R}^{2}\right)$ and the root mean square error normalized by the mean (NRMSE).

\section{Results}

\subsection{Air temperature and ER variability}

During the period of experiments, mean surface air temperatures were about $14-15{ }^{\circ} \mathrm{C}$ for all sites, except for LGT which was $20.8 \pm 7.4{ }^{\circ} \mathrm{C}$, (Figure $2-\mathrm{H}$ ). The lowest mean temperature and standard deviation were found at BDZ: $14.4 \pm 3.3{ }^{\circ} \mathrm{C}$ (Figure $2-\mathrm{E}$ ). In LDM and FRN, the mean surface air temperatures were respectively $14.9 \pm 8.7{ }^{\circ} \mathrm{C}$ and $15.0 \pm 10.3{ }^{\circ} \mathrm{C}$ (Figure $2-\mathrm{F}, \mathrm{G}$ ). Surface air temperature was the highest in FRN.

At $-5 \mathrm{~cm}$ depth, BDZ and LGT had lower mean peat temperatures than their air surface counterparts: $14.1 \pm 1.5{ }^{\circ} \mathrm{C}$ and $20.3 \pm 1.7{ }^{\circ} \mathrm{C}$ respectively, whereas the opposite was observed in FRN and LDM with $16.3 \pm 2.4{ }^{\circ} \mathrm{C}$ and $15.9 \pm 1.0{ }^{\circ} \mathrm{C}$ respectively. Mean soil temperatures were still 
higher at $-10 \mathrm{~cm}$ for both sites, but only in LDM at $-20 \mathrm{~cm}$. At $-30 \mathrm{~cm}$ the soil temperature amplitude ranged from 0.2 in LDM to 0.6 in LGT and FRN. Overall conditions were warmer in LGT than in the other sites and LDM, despite a large amplitude of surface air temperature, had a particularly low soil temperature amplitude.

In terms of ER, mean and variability were the lowest in FRN among all sites $(1.75 \pm 0.83$ $\mu \mathrm{mol} \mathrm{m}{ }^{-2} \mathrm{~s}^{-1}$, Figure $\left.2-\mathrm{B}\right)$. The highest variability and mean ER $\left(6.13 \pm 2.81 \mu \mathrm{mol} . \mathrm{m}^{-2} \cdot \mathrm{s}^{-1}\right.$, Figure 2 - C) were observed in LDM. On this site replicates had different behaviours even though they were close to each other and in a similar environment. In BDZ and LGT, ER mean values were 3.12 \pm 0.92 and $4.10 \pm 1.15 \mu$ mol. $\mathrm{m}^{-2} \cdot \mathrm{s}^{-1}$ respectively (Figure $2-\mathrm{A}, \mathrm{B}$ ).

\subsection{ER and soil temperature synchronisation}

Figure 2 shows that the deeper the temperature was measured, the greater the shift with respect to ER. Taking this shift into account by synchronising soil temperatures with ER led to a significant positive linear correlation between the temperature measurement depth and the synchronisation time-delay (all sites pooled, $\mathrm{R}^{2}=0.94, \mathrm{p}<0.001$; Figure 3 ). The range of estimated time-delays decreased with depth up to $-20 \mathrm{~cm}$. At this depth the time-delay was 12 hours, i.e. a phase inversion on a daily timescale. For the three sites other than LDM, the slopes of the timedelay and measurement depth relationship were in a close range: $0.56,0.54,0.52$ for FRN, BDZ and LGT respectively. The relationship for LDM was higher at $-30 \mathrm{~cm}$, leading to a steeper slope $(0.66)$ than in the other sites (Figure 3). At the other depths, this site always had the highest time-delay, though the values were close to those of the other sites. BDZ always had the lowest time-delay, but like LDM, the values were close to those of the other sites, although slightly lower at $-5 \mathrm{~cm}$ depth.

\subsection{ER and temperature relationship}

For both types of model (using non-synchronised and synchronised data), the differences 
between the 3 tested models were very small. The greatest differences, in $\mathrm{R}^{2}$ values, were 0.07 and 0.05 for non-synchronised and synchronised data respectively, whereas differences in NRMSE maximum values were 1.28 and 1.14 (Table B.3). In most cases the linear model led to a slightly better $\mathrm{R}^{2}$ than the others. As the differences between equations were small, however, we will describe the exponential model in the following sections, because (i) it is the most widely used model to describe the ER-temperature relationship and (ii) the $\mathrm{Q}_{10}$ value can be derived from this equation. This will allow the comparison of the results of our study to others.

The relationship between air temperature and ER, using the exponential model, was better in LGT and FRN $\left(\mathrm{R}^{2}>0.55\right)$ than in LDM and LDM $\left(\mathrm{R}^{2}<0.35\right)$ (Figure 4). Nevertheless in all sites and with both linear and exponential models, using synchronised soil temperatures gave a better account of the ER variability than their non-synchronised counterparts (Figure 4). The goodness of fit $\left(\mathrm{R}^{2}\right)$ increased on average by 0.26 to 0.35 at $-5 \mathrm{~cm}$ and $-10 \mathrm{~cm}$ depth respectively. The degree of improvement varied however between sites. For instance, at $-5 \mathrm{~cm}$ depth $\mathrm{R}^{2}$ between synchronised and non-synchronised models increased by only 0.04 in BDZ while it increased by 0.47 in FRN. The improvement gained by using synchronised data was higher at $-5 \mathrm{~cm}$ and $-10 \mathrm{~cm}$ than at deeper layers, with $0.12,0.11$ on average for -20 and $-30 \mathrm{~cm}$ depth (Figure 4 ).

A similar observation can be made for NRMSE. Regardless of some exceptions at deeper layers especially at $-20 \mathrm{~cm}$ depth, the NRMSE values show that using synchronised data rather than non-synchronised ones improved the model representation of ER variability at a daily timescale, indicating that depth measurements dependence is smaller for models using synchronised data than for models using non-synchronised data. However with increasing depth $\mathrm{R}^{2}$ values still decreased and NRMSE values still increased. For FRN, LDM and LGT, synchronised data at $-5 \mathrm{~cm}$ depth gave a better account of the ER variability than surface air temperature (Figure 4). This was not the case in LDM, where temperature at the surface was the best descriptor of ER. For both $\mathrm{R}^{2}$ and NRMSE the values at $-20 \mathrm{~cm}$ depth were better than those observed at -10 or $-30 \mathrm{~cm}$ depth. This 
pattern was observed with different magnitudes among sites, and was particularly visible in FRN and LGT. For the most part, the synchronisation of data led to higher $\mathrm{R}^{2}$ and smaller NRMSE values for models using one soil temperature, at a daily scale on sphagnum-dominated peatlands.

\section{4. $Q_{10}$ evolution}

The $\mathrm{Q}_{10}$ stood between 0 and 2.5 for non-synchronised data with a maximum at $-5 \mathrm{~cm}$ depth. Average values were 1.4, 2.4 and 1.3, at the surface, -5 and $-10 \mathrm{~cm}$ depth respectively (Figure 5). Average $\mathrm{Q}_{10}$ values at the surface and $-10 \mathrm{~cm}$ depth were very similar. However there was much more variability at $-10 \mathrm{~cm}$ depth, where the values ranged from 0.1 to 2.1 , than at the surface where the values stood between 1.3 and 1.5 . Beyond $-10 \mathrm{~cm}$ depth $\mathrm{Q}_{10}$ values fell almost to 0 , while for non-synchronised data $\mathrm{Q}_{10}$ values greatly increased with depth, reaching meaningless values. $\mathrm{Q}_{10}$ values estimated with surface temperature were very similar between sites with an average of 1.4 (Figure 5). It increased to about 2.5 at $-5 \mathrm{~cm}$ depth, with both synchronised and non-synchronised data. Below this depth, $\mathrm{Q}_{10}$ estimated with both methods either decreased downwards (nonsynchronised) or increased (synchronised data) to unrealistic values (Figure 5).

\section{Discussion}

\subsection{ER differences between sites}

The ER fluxes calculated in the 4 sites were in the same order of magnitude as those of peatlands found in the literature: Bortoluzzi et al. (2006), found ER values ranging from 2 to 5 $\mu \mathrm{mol} . \mathrm{m}^{-2} \cdot \mathrm{s}^{-1}$ during the same period as this study, i.e. July to October 2004, as well as Juszczak et al. (2013) with value between 2.6 to $5.4 \mu \mathrm{mol} . \mathrm{m}^{-2} . \mathrm{s}^{-1}$ (June to August 2008-2009). In the present study, the models performed poorly in 2 sites, BDZ and LDM. For BDZ, amplitudes of both ER and temperatures were low (Figure 2 - A, E) making the model representation of ER possible only on a short temperature span. With such low ranges of both ER and temperature, it can be assumed that 
ER variability was due to the variability between plots. For LDM, the ER fluxes were measured in plots that were more heterogeneous than expected, resulting in strong variability (Figure $2-\mathrm{C}$ ). This observation is consistent with the high NRMSE value calculated for this site $(39.3 \%$ for BDZ against $26.1 \%$ for $\mathrm{LDM}$ ) whereas the $\mathrm{R}^{2}$ values for these two sites were close, 0.19 and 0.32 for BDZ and LDM respectively, using surface air temperature and an exponential relationship. In Frasne the NRMSE values were high with respect to $\mathrm{R}^{2}$ values, this result can be explained by the fact that the mean ER flux was low $\left(1.75 \mu \mathrm{mol} . \mathrm{m}^{-2} . \mathrm{s}^{-1}\right)$ and thus had a strong influence on NRMSE as we used mean normalization. Finally at $-20 \mathrm{~cm}$ depth, models using non-synchronised data showed, an increase in $\mathrm{R}^{2}$ and a decrease in NRMSE which was more or less observable in the different sites. At this depth the temperature and the ER signal phases are opposed making the nonsynchronised models better at representing ER than at -10 or -30 centimetres but with a reverse relationship. The ER fluxes thus show different behaviours either in their amplitude or in their homogeneity.

\subsection{Time-delay between temperature and ER}

Time-delays between soil temperatures and ER occur in Sphagnum-dominated peatlands. They occur even close to the soil surface and increase with depth. The relationship between timedelays and depth was similar in all the studied sites although LDM had slightly higher time-delays. The overall delay observed in peat soils, 0.57 hours per centimetre, was higher than those found by Pavelka et al. (2007) in a forest and in a grassland ecosystem and by Parkin \& Kaspar (2003) on two agricultural soils ( 0.4 and 0.5 hours per centimetre respectively). This is coherent with the fact that peat soil has a lower thermal diffusivity than mineral soils (Farouki, 1981; Arya, 2001). LDM was the only site with a slightly higher slope especially at $-30 \mathrm{~cm}$. This was expected as soil diffusivity increases with wetness (Hillel, 2003) and LDM was the site with the lowest water table level. This was confirmed by thermal conductivity measurements conducted on the peat cores (data 
not shown). Overall, it should be noted that the time-delays were similar in all the studied sites despite their variability in terms of ER fluxes.

\subsection{Synchronising ER and temperature improves ER sensitivity to temperature}

In spite of the importance of lags between physical phenomenona and biological activities (Vargas et al., 2010), few studies have addressed the effect of time-delays between soil temperature and global biological activity (ER) at the daily timescale. At this scale, we showed in peatlands that using synchronised data improved the model representation of the temperature sensitivity of ER. The improvement provided by synchronisation was evidenced at shallow depth. The best goodnessof-fit obtained with synchronised data and models using one temperature, was found at $-5 \mathrm{~cm}$ depth. The fact that ER was better correlated to synchronized temperature at the depth of $5 \mathrm{~cm}$ (in most sites) shows that the metabolism of the respiring organisms could not efficiently respond to the temperature amplitude imposed at the surface of the soil. Above $5 \mathrm{~cm}$, an increase of temperature is not necessarily followed by an increase of respiration. Below $5 \mathrm{~cm}$, the dependence of ER on temperature synchronisation with depth decreased, as also found by Pavelka et al. (2007). Such a lesser depth effect could be explained by a simultaneous decrease in temperature amplitude. Because the goodness-of-fit of the non-synchronised data increases at $-20 \mathrm{~cm}$, the synchronisation effect strongly decreases at this depth. This pattern is visible, with various amplitudes, in the different sites. It is explained by the $12 \mathrm{~h}$ time-delay (Figure 3) corresponding to a phase inversion that occurs at this depth between the ER and the daily temperature courses. Such a phase inversion was found deeper, at $-30 \mathrm{~cm}$ by Pavelka et al. (2007), due to a higher temperature diffusivity in mineral soils. Finally in our study these models, using synchronised $-5 \mathrm{~cm}$ depth temperature, show slightly higher $\mathrm{R}^{2}$ and lower NRMSE values than those using surface air temperature.

\section{4. $Q_{10}$ sensitivity to temperature depth and synchronisation}

In shallow layers $(\leq 10 \mathrm{~cm})$, the $\mathrm{Q}_{10}$ values calculated with non-synchronised data in the 
ranges that are usually reported, i.e. between 1.3 to 3.3 (Raich \& Schlesinger, 1992). At deeper levels in the peat profile $(\geq 10 \mathrm{~cm}$ ), they reach 0 as the relationship between ER and the temperature weakens, and is not compensated by a long term evolution. A similar behaviour was found by Pavelka et al. (2007) even if this $\mathrm{Q}_{10}$ decrease with depth is not usually seen and most studies show the opposite, namely an increase in $\mathrm{Q}_{10}$ values with depth (Graf et al., 2008). This apparent contradiction may be explained by the length of the study. Because of its short duration, the effect of the time-delays on ER dominated the temperature effect. Synchronisation also led to meaningless high $\mathrm{Q}_{10}$ values because synchronisation can explain a higher proportion of ER flux with a smaller temperature variation. Temperature amplitude decreases with depth because of the heat absorption along the path of heat propagation.

\section{Conclusions}

We showed that the time-delays between ER and soil temperatures in peat soils at different depths are significant on a daily timescale. The signals are shifted approximately 30 minutes every centimetre in all studied sites, leading to longer time-delay than those found in mineral soils. At this scale the use of synchronised soil temperature, to take into account these time-delays, can improve the model representation of ER particularly in the first 10 centimetres. Thus the synchronised temperature at the $-5 \mathrm{~cm}$ depth seems to be well suited to model ER as it is leading, in most sites, to higher $\mathrm{R}^{2}$ and lower NRMSE than surface air temperature. With high frequency measurements (automated chamber technique is increasingly used) the temperature depth used to model ER is critical especially to assess processes that occur at a daily time scale. Thus the synchronisation can be a way to improve ER model representation. Temperature measurements at different depths are easy to conduct, robust to harsh conditions and can be powered by a small solar panel. A calibration campaign with human manipulated closed chambers could be carried out to assess ER variability at different timescales. Coupling temperature profile and punctual ER measurements and then using 
synchronised data in models may be a good alternative in sites where automated chambers are not easily implantable.

\section{Acknowledgements}

The work was funded as part of the Peatland National Observatory Service (Service national d'observation Tourbières, certified by the CNRS/INSU) as the four studied sites are part of this Service. The authors are also indebted to the site managers for permitting access to the studied peatlands. We also acknowledge support from Labex VOLTAIRE (ANR-10-LABX-100-01). Finally we would like to thank Elizabeth Rowley-Jolivet for corrections to the manuscript.

\section{References}

Arya, S. P. (2001). Introduction to Micrometeorology volume 79 of International Geophysics Series. Academic Press.

Ballantyne, D. M., Hribljan, J. A., Pypker, T. G., \& Chimner, R. A. (2014). Long-term water table manipulations alter peatland gaseous carbon fluxes in northern Michigan. Wetlands Ecol. Manage., 22, 35-47. doi:10.1007/s11273-013-9320-8.

Beer, C., Reichstein, M., Tomelleri, E., Ciais, P., Jung, M., Carvalhais, N., R״odenbeck, C., Arain, M. A., Baldocchi, D., Bonan, G. B., Bondeau, A., Cescatti, A., Lasslop, G., Lindroth, A., Lomas, M., Luyssaert, S., Margolis, H., Oleson, K. W., Roupsard, O., Veenendaal, E., Viovy, N., Williams, C., Woodward, F. I., \& Papale, D. (2010). Terrestrial Gross Carbon Dioxide Uptake: Global Distribution and Covariation with Climate. Science, 329, 834-838. doi:10.1126/science. 1184984.

Bond-Lamberty, B., \& Thomson, A. (2010). Temperature-associated increases in the global soil respiration record. Nature, 464, 579-582. doi:10.1038/nature08930. 
Bortoluzzi, E., Epron, D., Siegenthaler, A., Gilbert, D., \& Buttler, A. (2006). Carbon balance of a European mountain bog at contrasting stages of regeneration. New Phytol., 172, 708-718. doi:10.1111/j.1469-8137.2006.01859.x.

Carvalhais, N., Forkel, M., Khomik, M., Bellarby, J., Jung, M., Migliavacca, M., Mu, M., Saatchi, S., Santoro, M., Thurner, M., \& others (2014). Global covariation of carbon turnover times with climate in terrestrial ecosystems. Nature, 514, 213-217.

Ciais, P., Sabine, C., Bala, G., Bopp, L., Brovkin, V., Canadell, J., Chhabra, A., DeFries, R., Galloway, J., Heimann, M., \& others (2014). Carbon and other biogeochemical cycles. In Climate Change 2013: The Physical Science Basis. Contribution of Working Group I to the Fifth Assessment Report of the Intergovernmental Panel on Climate Change (pp. 465-570). Cambridge University Press.

Curiel Yuste, J., Janssens, I. A., Carrara, A., \& Ceulemans, R. (2004). Annual Q 10 of soil respiration reflects plant phenological patterns as well as temperature sensitivity. Global Change Biol., 10, 161-169. doi:10.1111/j.1529-8817.2003.00727.x.

Darenova, E., Pavelka, M., \& Acosta, M. (2014). Diurnal deviations in the relationship between $\mathrm{CO}_{2}$ efflux and temperature: A case study. CATENA, 123, 263-269. doi:10.1016/j.catena. 2014.08.008.

Davidson, E. A., Janssens, I. A., \& Luo, Y. (2006). On the variability of respiration in terrestrial ecosystems: moving beyond $\mathrm{Q}_{10}$. Global Change Biol., 12, 154-164. doi:10.1111/j.13652486. 2005.01065.x.

Fang, C., \& Moncrieff, J. (2001). The dependence of soil $\mathrm{CO}_{2}$ efflux on temperature. Soil Biol. Biochem., 33, 155-165. doi:10.1016/S0038-0717(00)00125-5.

Farouki, O. (1981). Thermal properties of soils. Series on rock and soil mechanics. Trans Tech Pub., Rockport, MA. 
Gorham, E. (1991). Northern Peatlands: Role in the Carbon Cycle and Probable Responses to Climatic Warming. Ecol. Appl., 1, 182-195. doi:10.2307/1941811

Görres, C. M., Kutzbach, L., \& Elsgaard, L. (2014). Comparative modeling of annual $\mathrm{CO}_{2}$ flux of temperate peat soils under permanent grassland management. Agriculture, Ecosystems \& Environment, 186, 64-76. doi:10.1016/j.agee.2014.01.014.

Graf, A., Weihermüller, L., Huisman, J. A., Herbst, M., Bauer, J., \& Vereecken, H. (2008). Measurement depth effects on the apparent temperature sensitivity of soil respiration in field studies. Biogeosciences, 5, 1867-1898. doi:10.5194/bg-5-1175-2008.

Günther, A., Huth, V., Jurasinski, G., \& Glatzel, S. (2014). The effect of biomass harvesting on greenhouse gas emissions from a rewetted temperate fen. GCB Bioenergy, 7, (pp. 1092-1106). doi:10.1111/gcbb.12214.

Hillel, D. (2003). Soil temperature and heat flow. In Introduction to Environmental Soil Physics. Academic Press. \{DOI:10.1016/B978-012348655-4/50013-7\}.

Juszczak, R., Acosta, M., \& Olejnik, J. (2012). Comparison of daytime and nighttime ecosystem respiration measured by the closed chamber technique on temperate mire in Poland. Pol. J. Environ. Stud., 21, 643-658.

Juszczak. R., Humphreys, E., Acosta. M., Michalak-Galczewska, M., Kayzer, D., Olejnik, J. (2013). Ecosystem respiration in a heterogeneous temperate peatland and its sensitivity to peat temperature and water table depth. Plant and Soil. 366, 505-520, DOI 10.1007/s11104-012-1441-y.

Kennedy, G. W., \& Price, J. S. (2005). A conceptual model of volume-change controls on the hydrology of cutover peats. J. Hydrol., 302, 13-27. doi:10.1016/j.jhydrol.2004.06.024.

Kim, J., \& Verma, S. B. (1992). Soil surface $\mathrm{CO}_{2}$ flux in a Minnesota peatland. Biogeochemistry, 18, 37-51. doi:10.1007/BF00000425. 
Limpens, J., Berendse, F., Blodau, C., Canadell, J. G., Freeman, C., Holden, J., Roulet, N., Rydin, H., \& Schaepman-Strub, G. (2008). Peatlands and the carbon cycle: from local processes to global implications - a synthesis. Biogeosciences, 5, 1475-1491. doi:10.5194/bg-5-1475-2008.

Luo, Y., \& Zhou, X. (2006). Chapter 5 - Controlling factors. In Y. Luo, \& X. Zhou (Eds.), Soil Respiration and the Environment (pp. 79 - 105). Burlington: Academic Press. doi:10.1016/ B978012088782-8/50005-X.

Mahecha, M. D., Reichstein, M., Carvalhais, N., Lasslop, G., Lange, H., Seneviratne, S. I., Vargas, R., Ammann, C., Arain, M. A., Cescatti, A., Janssens, I. A., Migliavacca, M., Montagnani, L., \& Richardson, A. D. (2010). Global Convergence in the Temperature Sensitivity of Respiration at Ecosystem Level. Science, 329, 838-840. doi:10.1126/science.1189587.

Parkin, T. B., \& Kaspar, T. C. (2003). Temperature Controls on Diurnal Carbon Dioxide Flux. Soil Sci. Soc. Am. J., 67, 1763-1772. doi:10.2136/sssaj2003.1763.

Pavelka, M., Acosta, M., Marek, M. V., Kutsch, W., \& Janous, D. (2007). Dependence of the $\mathrm{Q}_{10}$ values on the depth of the soil temperature measuring point. Plant Soil, 292, 171-179. doi:10.1007/s11104-007-9213-9.

Phillips, C. L., Nickerson, N., Risk, D., \& Bond, B. J. (2011). Interpreting diel hysteresis between soil respiration and temperature. Global Change Biol., 17, 515-527. doi:10.1111/j.13652486. 2010.02250.x.

Pumpanen, J., Kolari, P., Ilvesniemi, H., Minkkinen, K., Vesala, T., Niinist”o, S., Lohila, A., Larmola, T., Morero, M., Pihlatie, M., Janssens, I., Yuste, J. C., Grünzweig, J. M., Reth, S., Subke, J.-A., Savage, K., Kutsch, W., Østreng, G., Ziegler, W., Anthoni, P., Lindroth, A., \& Hari, P. (2004). Comparison of different chamber techniques for measuring soil $\mathrm{CO}_{2}$ efflux. Agric. For. Meteorol., 123, 159-176. doi:10.1016/j.agrformet.2003.12.001.

Raich, J. W., \& Schlesinger, W. H. (1992). The global carbon dioxide flux in soil respiration 
and its relationship to vegetation and climate. Tellus B, 44, 81-99. doi:10.1034/j.16000889.1992.t01-1-00001.x.

Turunen, J., Tomppo, E., Tolonen, K., \& Reinikainen, A. (2002). Estimating carbon accumulation rates of undrained mires in Finland-application to boreal and subarctic regions. The Holocene, 12, 69-80. doi:10.1191/0959683602hl522rp.

Vargas, R., Baldocchi, D. D., Allen, M. F., Bahn, M., Black, T. A., Collins, S. L., Yuste, J. C., Hirano, T., Jassal, R. S., Pumpanen, J., \& Tang, J. (2010). Looking deeper into the soil: biophysical controls and seasonal lags of soil $\mathrm{CO}_{2}$ production and efflux. Ecol. Appl., 20, 1569- 1582. doi:10.1890/09-0693.1.

Zhu, X., Song, C., Swarzenski, C. M., Guo, Y., Zhang, X., \& Wang, J. (2015). Ecosystematmosphere exchange of $\mathrm{CO}_{2}$ in a temperate herbaceous peatland in the Sanjiang plain of north-east China. Ecol. Eng., 75, 16-23. doi:10.1016/j.ecoleng.2014.11.035.

\section{Supplementary data}

\section{A. Physico-chemical characterisation of the peat}

In the laboratory, two peat cores from each site were immersed in water for 24 hours to saturate the pores. Then, the cores were drained overnight to get rid of the water filling the effective porosity (the water not bound to grains). At $5 \mathrm{~cm}$ steps, a piece of peat with a known volume (V, $\mathrm{cm}^{3}$ ) was cut and weighed (W1, g). Then, the samples were dried at $50^{\circ} \mathrm{C}$ for 48 hours and weighed (W2, g). Total porosity $\left(\Phi_{\mathrm{T}}\right.$, dimensionless), retention porosity $\left(\Phi_{\mathrm{R}}\right.$, dimensionless), effective porosity $\left(\Phi_{\mathrm{E}}\right.$, dimensionless) and bulk density $\left(\mathrm{Bd}, \mathrm{g} . \mathrm{cm}^{-3}\right)$ were calculated as follows:

$$
\begin{aligned}
& \Phi_{\mathrm{T}}=1-\left(\left(\mathrm{W} 2 / \rho_{\text {peat }}\right) / \mathrm{V}\right) \\
& \Phi_{\mathrm{R}}=1-\left(\left(\mathrm{W} 1-\mathrm{W} 2 / \rho_{\text {peat }}\right) / \mathrm{V}\right)
\end{aligned}
$$




$$
\begin{aligned}
& \Phi_{\mathrm{E}}=\Phi_{\mathrm{T}}-\Phi_{\mathrm{R}} \\
& \mathrm{Bd}=\mathrm{W} 2 / \mathrm{V}
\end{aligned}
$$

Peat density ( $\left.\rho_{\text {peat }}\right)$ was set at 1.45 according to Kennedy \& Price (2005). Then the peat was crushed and C, Hydrogen $(\mathrm{H})$, Nitrogen $(\mathrm{N})$ and Sulfur $(\mathrm{S})$ analyses were performed with an elemental analyser (Thermo Flash analyser). Elemental compositions were similar in all sites: 1$3 \%, 4-6 \%$ and $<1 \%$ for $\mathrm{N}, \mathrm{H}$ and $\mathrm{S}$ respectively (Table A.1). C content was mainly between 40 and $50 \%$, except at the deeper levels in LDM and LGT where values were lower $(<32 \%)$. 
Table A.1: Peat chemical properties as a function of depth in $\mathrm{cm}$ : content $(\%) \mathrm{N}, \mathrm{C}, \mathrm{H}, \mathrm{S}$, the total, retention and effective porosity, $\Phi_{\mathrm{T}}, \Phi_{\mathrm{R}}, \Phi_{\mathrm{E}}$ respectively in $\mathrm{m}^{3} \cdot \mathrm{m}^{-3}$, solid peat volumic fraction in $\mathrm{m}^{3} \cdot \mathrm{m}^{-3}$ and the bulk density (Bd) in $\mathrm{g} . \mathrm{cm}^{-3}$.

\begin{tabular}{|c|c|c|c|c|c|c|c|c|c|}
\hline level & $\mathrm{N}$ & $\mathrm{C}$ & $\mathrm{H}$ & $S$ & $\Phi_{\mathrm{T}}$ & $\Phi_{\mathrm{R}}$ & $\Phi_{\mathrm{E}}$ & solid & $\mathrm{Bd}$ \\
\hline \multicolumn{10}{|l|}{ BDZ } \\
\hline $0-5$ & 1.76 & 41.84 & 6.05 & 0.05 & 0.99 & 0.47 & 0.52 & 0.01 & 0.03 \\
\hline $5-10$ & 1.99 & 43.99 & 6.18 & 0.07 & 0.97 & 0.78 & 0.19 & 0.03 & 0.06 \\
\hline $10-15$ & 2.28 & 45.38 & 6.35 & 0.1 & 0.96 & 0.92 & 0.04 & 0.04 & 0.10 \\
\hline $15-20$ & 2.92 & 44.95 & 6.23 & 0.23 & 0.95 & 0.82 & 0.13 & 0.05 & 0.11 \\
\hline $20-25$ & 3.14 & 39.01 & 5.31 & 0.23 & 0.93 & 0.90 & 0.04 & 0.07 & 0.16 \\
\hline $25-30$ & 2.50 & 31.15 & 4.28 & 0.13 & 0.89 & 0.86 & 0.03 & 0.11 & 0.24 \\
\hline \multicolumn{10}{|l|}{ FRN } \\
\hline $0-5$ & 1.73 & 43.67 & 6.24 & 0.00 & 0.99 & 0.40 & 0.58 & 0.01 & 0.03 \\
\hline $5-10$ & 1.55 & 43.35 & 5.97 & 0.00 & 0.98 & 0.59 & 0.40 & 0.02 & 0.03 \\
\hline $10-15$ & 1.69 & 43.49 & 6.17 & 0.00 & 0.98 & 0.89 & 0.09 & 0.02 & 0.05 \\
\hline $15-20$ & 1.63 & 43.06 & 5.97 & 0.00 & 0.98 & 0.89 & 0.09 & 0.02 & 0.05 \\
\hline $20-25$ & 1.30 & 43.68 & 6.29 & 0.05 & 0.98 & 0.93 & 0.04 & 0.02 & 0.05 \\
\hline $25-30$ & 1.48 & 43.44 & 6.21 & 0.03 & 0.98 & 0.87 & 0.11 & 0.02 & 0.05 \\
\hline \multicolumn{10}{|l|}{ LDM } \\
\hline $0-5$ & 1.36 & 45.63 & 5.69 & 0.25 & 0.97 & 0.62 & 0.35 & 0.03 & 0.07 \\
\hline $5-10$ & 3.08 & 47.37 & 5.37 & 0.09 & 0.95 & 0.74 & 0.21 & 0.05 & 0.11 \\
\hline $10-15$ & 2.73 & 48.34 & 5.63 & 0.10 & 0.94 & 0.94 & 0.00 & 0.06 & 0.13 \\
\hline $15-20$ & 2.54 & 48.67 & 5.64 & 0.30 & 0.96 & 0.81 & 0.15 & 0.04 & 0.10 \\
\hline $20-25$ & 2.08 & 46.99 & 5.80 & 0.23 & 0.97 & 0.89 & 0.08 & 0.03 & 0.07 \\
\hline $25-30$ & 1.57 & 45.65 & 6.23 & 0.21 & 0.97 & 0.89 & 0.08 & 0.03 & 0.07 \\
\hline \multicolumn{10}{|l|}{ LGT } \\
\hline $0-5$ & 1.55 & 38.33 & 5.23 & 0.05 & 0.97 & 0.61 & 0.36 & 0.03 & 0.05 \\
\hline $5-10$ & 2.35 & 41.31 & 4.66 & 0.20 & 0.93 & 0.83 & 0.10 & 0.07 & 0.08 \\
\hline $10-15$ & 2.34 & 43.81 & 5.72 & 0.18 & 0.91 & 0.89 & 0.02 & 0.09 & 0.10 \\
\hline $15-20$ & 1.99 & 43.17 & 5.45 & 0.10 & 0.89 & 0.87 & 0.01 & 0.11 & 0.13 \\
\hline $20-25$ & 1.90 & 37.91 & 4.83 & 0.05 & 0.88 & 0.83 & 0.05 & 0.12 & 0.15 \\
\hline $25-30$ & 1.32 & 18.95 & 2.32 & 0.01 & 0.79 & 0.76 & 0.03 & 0.21 & 0.28 \\
\hline
\end{tabular}




\section{B. Models parameters and quality indicators ( $R^{2}$ and NRMSE)}

Table B1: Non-synchronised models parameters (par) estimate for the three equations. With the standard error (se) and p-values: <0.05 (*), <0.01 (**), <0.001(***). (Bernadouze: BDZ, Frasne: FRN, Landemarais: LDM, La Guette: LGT).

\begin{tabular}{|c|c|c|c|c|c|c|c|c|}
\hline \multirow[b]{2}{*}{ depth } & \multirow[b]{2}{*}{ par } & \multicolumn{3}{|c|}{ linear } & \multicolumn{2}{|c|}{ exponential } & \multicolumn{2}{|c|}{ arrhenius } \\
\hline & & value & se & p-value & value se & p-value & value se & p-value \\
\hline \multicolumn{9}{|l|}{ BDZ } \\
\hline \multirow[t]{2}{*}{0} & $\alpha$ & 1.2 & \pm 0.22 & $* * *$ & $0.48 \pm 0.08$ & $* * *$ & $13.32 \pm 1.49$ & $* * *$ \\
\hline & $\beta$ & 0.13 & \pm 0.01 & $* * *$ & $0.04 \pm 0.01$ & $* * *$ & $-3516.01 \quad \pm 427$ & $* * *$ \\
\hline \multirow[t]{2}{*}{-5} & $\alpha$ & -0.92 & \pm 0.44 & $*$ & $-0.2 \pm 0.15$ & - & $27.44 \pm 3.08$ & $* * *$ \\
\hline & $\beta$ & 0.29 & \pm 0.03 & $* * *$ & $0.09 \pm 0.01$ & $* * *$ & $-7568.79 \pm 886$ & $* * *$ \\
\hline \multirow[t]{2}{*}{-10} & $\alpha$ & 0.57 & \pm 0.96 & - & $0.15 \pm 0.33$ & - & $20.69 \pm 6.78$ & $* *$ \\
\hline & $\beta$ & 0.19 & \pm 0.07 & $* *$ & $0.07 \pm 0.02$ & $* *$ & $-5623.83 \pm 1945$ & $* *$ \\
\hline \multirow[t]{2}{*}{-20} & $\alpha$ & 13.2 & \pm 2.80 & $* * *$ & $3.81 \pm 0.97$ & $* * *$ & $-57.05 \pm 20.65$ & $* *$ \\
\hline & $\beta$ & -0.75 & \pm 0.21 & $* * *$ & $-0.2 \pm 0.07$ & $* *$ & $16663.71 \pm 5919$ & $* *$ \\
\hline \multirow[t]{2}{*}{-30} & $\alpha$ & 24.91 & \pm 8.23 & $* *$ & $7.81 \pm 2.81$ & $* *$ & $-145.42 \pm 61$ & $*$ \\
\hline & $\beta$ & -1.66 & \pm 0.63 & $* *$ & $-0.51 \pm 0.21$ & $*$ & $41948.79 \pm 17582$ & $*$ \\
\hline \multicolumn{9}{|l|}{ FRN } \\
\hline \multirow[t]{2}{*}{0} & $\alpha$ & 0.78 & \pm 0.05 & $* * *$ & $-0.11 \pm 0.03$ & $* * *$ & $11.23 \pm 0.49$ & $* * *$ \\
\hline & $\beta$ & 0.06 & \pm 0.00 & $* * *$ & $0.04 \pm 0.00$ & $* * *$ & $-3104.47 \pm 140$ & $* * *$ \\
\hline \multirow[t]{2}{*}{-5} & $\alpha$ & -0.68 & \pm 0.30 & $*$ & $-1.04 \pm 0.17$ & $* * *$ & $26.84 \pm 3.05$ & $* * *$ \\
\hline & $\beta$ & 0.15 & \pm 0.02 & $* * *$ & $0.09 \pm 0.01$ & $* * *$ & $-7639.89 \pm 884$ & $* * *$ \\
\hline \multirow[t]{2}{*}{-10} & $\alpha$ & 2.79 & \pm 0.55 & $* * *$ & $0.69 \pm 0.33$ & $*$ & $-4.01 \pm 6$ & - \\
\hline & $\beta$ & -0.07 & \pm 0.04 & - & $-0.02 \pm 0.02$ & - & $1288.6 \pm 1732$ & - \\
\hline \multirow[t]{2}{*}{-20} & $\alpha$ & 19.81 & \pm 1.50 & $* * *$ & $9.96 \pm 0.92$ & $* * *$ & $-188.36 \pm 18.28$ & $* * *$ \\
\hline & $\beta$ & -1.25 & \pm 0.10 & $* * *$ & $-0.66 \pm 0.06$ & $* * *$ & $54320.8 \pm 5261$ & $* * *$ \\
\hline \multirow[t]{2}{*}{-30} & $\alpha$ & 15.72 & \pm 4.65 & $* * *$ & $8.49 \pm 2.73$ & $* *$ & $-165.41 \pm 56$ & $* *$ \\
\hline & $\beta$ & & \pm 0.33 & $* *$ & $-0.58 \pm 0.20$ & $* *$ & $47621.36 \pm 16176$ & $* *$ \\
\hline \multicolumn{9}{|c|}{ LDM } \\
\hline \multirow[t]{2}{*}{0} & $\alpha$ & 3.18 & \pm 0.31 & $* * *$ & $1.22 \pm 0.05$ & $* * *$ & $10.46 \pm 0.76$ & $* * *$ \\
\hline & $\beta$ & 0.18 & \pm 0.02 & $* * *$ & $0.03 \pm 0.00$ & $* * *$ & $-2529.07 \pm 220$ & $* * *$ \\
\hline \multirow[t]{2}{*}{-5} & $\alpha$ & -0.87 & \pm 2.50 & - & $0.41 \pm 0.40$ & - & $25.29 \pm 7.15$ & $* * *$ \\
\hline & $\beta$ & 0.44 & \pm 0.16 & $* *$ & $0.08 \pm 0.02$ & $* *$ & $-6818.61 \pm 2068$ & $* *$ \\
\hline \multirow[t]{2}{*}{-10} & $\alpha$ & 28.41 & \pm 5.50 & $* * *$ & $4.8 \pm 0.88$ & $* * *$ & $-55.31 \pm 16.3$ & $* * *$ \\
\hline & $\beta$ & -1.42 & \pm 0.35 & $* * *$ & $-0.2 \pm 0.06$ & $* * *$ & $16473.53 \pm 4704$ & $* * *$ \\
\hline \multirow[t]{2}{*}{-20} & $\alpha$ & 104.7 & \pm 18.0 & $* * *$ & $17.18 \pm 3.01$ & $* * *$ & $-290.21 \pm 57$ & $* * *$ \\
\hline & $\beta$ & -6.45 & \pm 1.23 & $* * *$ & $-1.01 \pm 0.20$ & $* * *$ & $84216.76 \pm 16414$ & $* * *$ \\
\hline
\end{tabular}




\begin{tabular}{|c|c|c|c|c|c|c|c|}
\hline-30 & $\alpha$ & $-116.4 \pm 40.7$ & $* *$ & $-14.16 \pm 6.52$ & $*$ & $310.7 \pm 127$ & $*$ \\
\hline & $\beta$ & $8.28 \pm 2.75$ & $* *$ & $1.07 \pm 0.44$ & $*$ & $-88987.6 \pm 36553$ & $*$ \\
\hline LGT & & & & & & & \\
\hline 0 & $\alpha$ & $1.55 \pm 0.13$ & $* * *$ & $0.77 \pm 0.03$ & $* * *$ & $9.67 \pm 0.43$ & $* * *$ \\
\hline & $\beta$ & $0.12 \pm 0.01$ & $* * *$ & $0.03 \pm 0.00$ & $* * *$ & $-2444.08 \pm 128$ & $* * *$ \\
\hline-5 & $\alpha$ & $-3.36 \pm 0.66$ & $* * *$ & $-0.4 \pm 0.17$ & $*$ & $26.88 \pm 2.39$ & $* * *$ \\
\hline & $\beta$ & $0.37 \pm 0.03$ & $* * *$ & $0.09 \pm 0.01$ & $* * *$ & $-7487.92 \pm 702$ & $* * *$ \\
\hline-10 & $\alpha$ & $-2.21 \pm 1.27$ & - & $-0.14 \pm 0.31$ & - & $23.72 \pm 4.65$ & $* * *$ \\
\hline & $\beta$ & $0.32 \pm 0.06$ & $* * *$ & $0.08 \pm 0.02$ & $* * *$ & $-6548.34 \pm 1364$ & $* * *$ \\
\hline-20 & $\alpha$ & $50.67 \pm 4.18$ & $* * *$ & $12.23 \pm 1.06$ & $* * *$ & $-168.07 \pm 16.5$ & $* * *$ \\
\hline & $\beta$ & $-2.49 \pm 0.22$ & $* * *$ & $-0.58 \pm 0.06$ & $* * *$ & $49464.16 \pm 4820$ & $* * *$ \\
\hline-30 & $\alpha$ & $60.7 \pm 8.92$ & $* * *$ & $14.87 \pm 2.22$ & $* * *$ & $-218.04 \pm 36.0$ & $* * *$ \\
\hline & $\beta$ & $-3.16 \pm 0.50$ & $* * *$ & $-0.75 \pm 0.12$ & $* * *$ & $63875.6 \pm 10484$ & $* * *$ \\
\hline
\end{tabular}

Table B2: Synchronised models parameters (par) estimate for the three equations, with standard error (se) and pvalues: <0.05 (*), <0.01 (**), <0.001(***). (Bernadouze: BDZ, Frasne: FRN, Landemarais: LDM, La Guette: LGT).

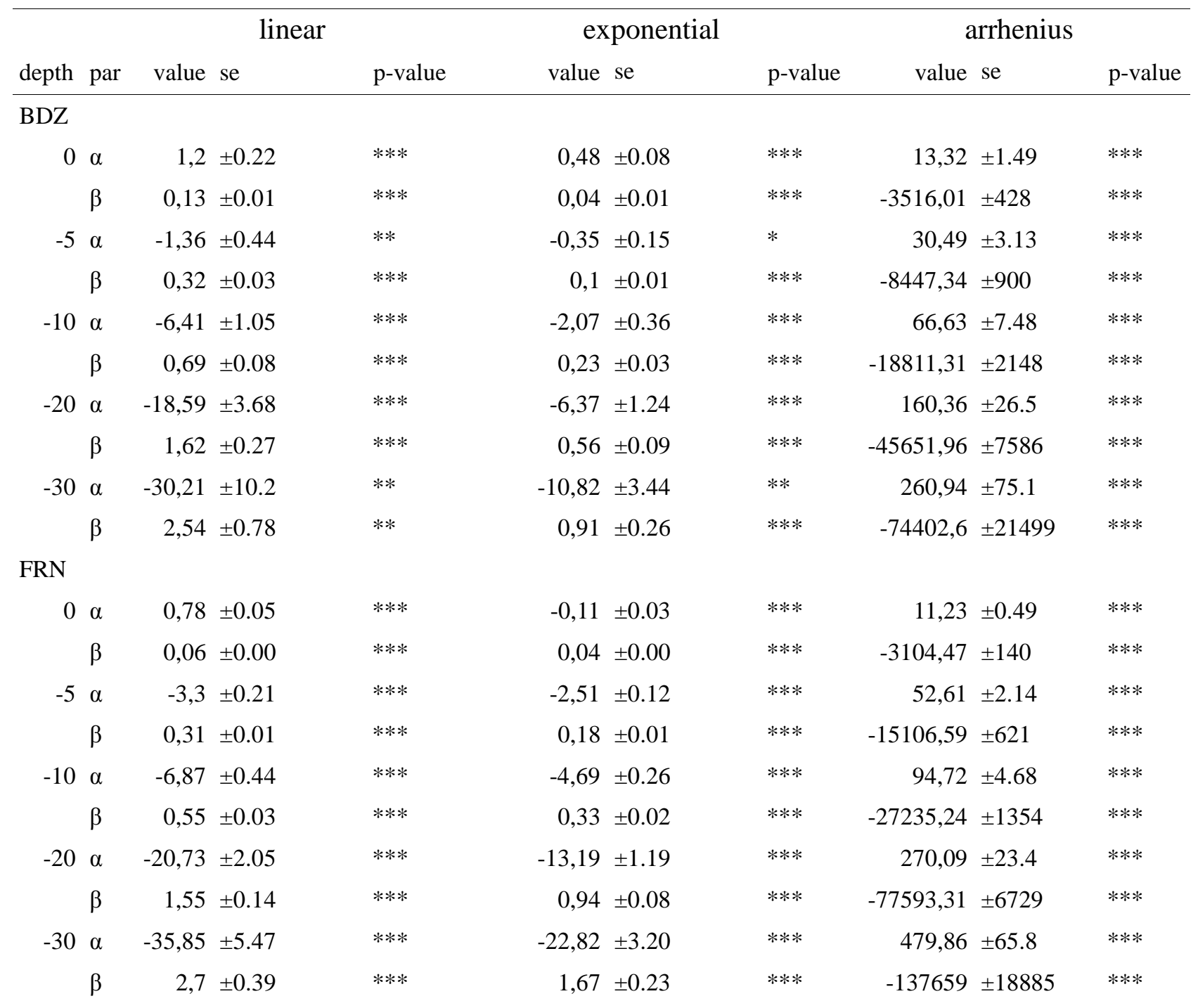


LDM

$\begin{array}{rrrrr}0 & \alpha & 3,18 \pm 0.31 & * * * \\ & \beta & 0,18 \pm 0.02 & * * * \\ -5 & \alpha & -15,25 \pm 2.51 & * * * \\ & \beta & 1,33 \pm 0.16 & * * * \\ -10 & \alpha & -31,61 \pm 6.13 & * * * \\ & \beta & 2,41 \pm 0.39 & * * * \\ -20 & \alpha & -92,44 \pm 20.9 & * * * \\ & \beta & 6,46 \pm 1.37 & * * * \\ -30 & \alpha & -497,5 \pm 92.6 & * * * \\ & \beta & 34,11 \pm 6.27 & * * *\end{array}$

$$
\begin{array}{rr}
1,22 & \pm 0.05 \\
0,03 & \pm 0.00 \\
-1,98 & \pm 0.39 \\
0,23 & \pm 0.02 \\
-5,03 & \pm 0.95 \\
0,43 & \pm 0.06 \\
-16,3 & \pm 3.24 \\
1,18 & \pm 0.21 \\
-76,84 & \pm 14.7 \\
5,32 & \pm 0.99
\end{array}
$$

$\begin{array}{rrrrr}0 & \alpha & & 1,55 & \pm 0.13 \\ & \beta & 0,12 & \pm 0.01\end{array}$

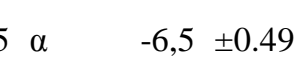

$\beta \quad 0,52 \pm 0.02$

$\begin{array}{llll}-10 & \alpha & -13,26 \pm 0.85\end{array}$

$\beta \quad 0,88 \pm 0.04$

$\begin{array}{llll}-20 & \alpha & -55,65 & \pm 3.51\end{array}$

$\beta \quad 3,2 \pm 0.19$

$\begin{array}{lll}-30 & \alpha & -121,3 \pm 10.5\end{array}$

$\beta \quad 7,01 \quad \pm 0.59$

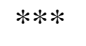

$* * *$
$* * *$
$* * *$
$* * *$
$* * *$
$* * *$
$* * *$
$* * *$
$* * *$

$* * *$
$0,77 \pm 0.03$

$0,03 \pm 0.00$

$-1,14 \pm 0.13$

$230,12 \pm 0.01$

$-2,74 \pm 0.22$

$0,21 \pm 0.01$

$-12,82 \pm 0.89$

$0,76 \pm 0.05$

$-28,39 \pm 2.64$

$1,66 \pm 0.15$

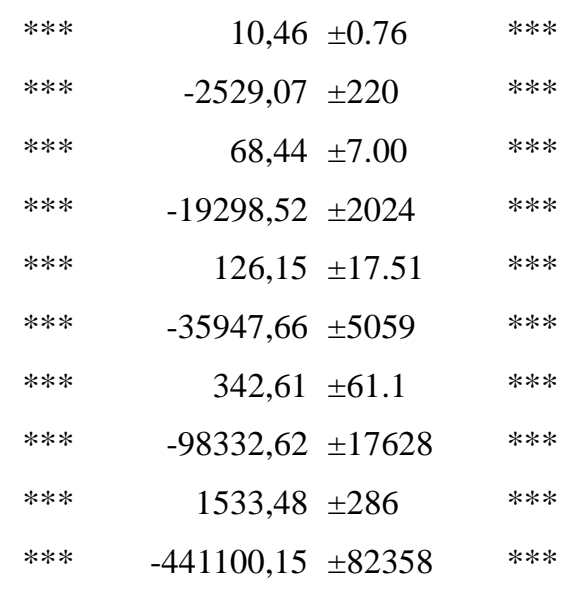

***

***

$* * *$

***

\begin{tabular}{|c|c|c|c|c|c|c|c|c|c|c|c|c|}
\hline \multirow[b]{3}{*}{ depth } & \multicolumn{6}{|c|}{ Non-synchronised } & \multicolumn{6}{|c|}{ Synchronised } \\
\hline & \multicolumn{2}{|c|}{ linear } & \multicolumn{2}{|c|}{ exponential } & \multicolumn{2}{|c|}{ arrhenius } & \multicolumn{2}{|c|}{ linear } & \multicolumn{2}{|c|}{ exponential } & \multicolumn{2}{|c|}{ arrhenius } \\
\hline & $\mathrm{R}^{2}$ & NRMSE & $\mathrm{R}^{2}$ & NRMSE & $\mathrm{R}^{2}$ & NRMSE & $\mathrm{R}^{2}$ & NRMSE & $\mathrm{R}^{2}$ & NRMSE & $\mathrm{R}^{2}$ & NRMSE \\
\hline \multicolumn{13}{|l|}{ BDZ } \\
\hline 0 & 0.22 & 25.88 & 0.19 & 26.09 & 0.19 & 26.09 & 0.22 & 25.88 & 0.19 & 26.09 & 0.19 & 26.09 \\
\hline-5 & 0.23 & 25.66 & 0.20 & 25.89 & 0.20 & 25.89 & 0.27 & 25.18 & 0.24 & 25.40 & 0.24 & 25.40 \\
\hline-10 & 0.02 & 28.92 & 0.03 & 29.26 & 0.03 & 29.26 & 0.23 & 25.72 & 0.22 & 25.90 & 0.22 & 25.91 \\
\hline-20 & 0.04 & 28.64 & 0.03 & 28.98 & 0.03 & 28.98 & 0.13 & 27.79 & 0.13 & 28.16 & 0.13 & 28.15 \\
\hline-30 & 0.02 & 28.93 & 0.02 & 29.28 & 0.02 & 29.28 & 0.05 & 29.54 & 0.05 & 29.92 & 0.05 & 29.92 \\
\hline \multicolumn{13}{|l|}{ FRN } \\
\hline 0 & 0.66 & 27.58 & 0.63 & 26.74 & 0.63 & 26.96 & 0.66 & 27.58 & 0.63 & 26.74 & 0.63 & 26.96 \\
\hline-5 & 0.19 & 42.34 & 0.21 & 43.00 & 0.21 & 43.01 & 0.68 & 26.34 & 0.68 & 25.02 & 0.68 & 25.06 \\
\hline-10 & 0.01 & 46.73 & 0.00 & 48.01 & 0.00 & 48.01 & 0.59 & 29.98 & 0.60 & 29.20 & 0.60 & 29.22 \\
\hline-20 & 0.34 & 38.29 & 0.27 & 38.78 & 0.27 & 38.77 & 0.34 & 38.05 & 0.36 & 39.17 & 0.36 & 39.16 \\
\hline-30 & 0.03 & 46.30 & 0.03 & 47.47 & 0.03 & 47.47 & 0.18 & 43.66 & 0.19 & 44.75 & 0.19 & 44.74 \\
\hline
\end{tabular}

$* * *$

***

***

***

***

*** $*$

$\begin{array}{rlr}9,67 & \pm 0.43 & * * * \\ -2444,08 & \pm 128 & * * * \\ 37,67 & \pm 1.84 & * * * \\ -10652,88 & \pm 540 & * * * \\ 62,38 & \pm 3.23 & * * * \\ -17873,91 & \pm 947 & * * * \\ 223,13 \pm 13.9 & * * * \\ -64728,71 \pm 4071 & * * * \\ 486,01 & \pm 43.0 & * * * \\ -141068 & \pm 12525 & * * *\end{array}$

Table B3: $R^{2}$ and NRMSE profile with depth for models using non-synchronised and synchronised data and for the three equations 
LDM

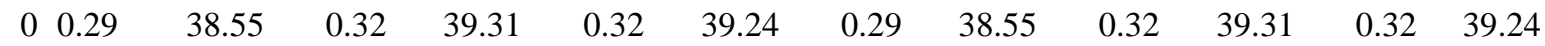

$\begin{array}{lllllllllllll}-5 & 0.03 & 45.18 & 0.04 & 46.06 & 0.04 & 46.07 & 0.21 & 40.63 & 0.25 & 41.58 & 0.25 & 41.57\end{array}$

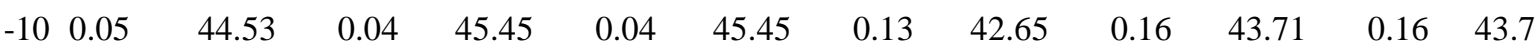

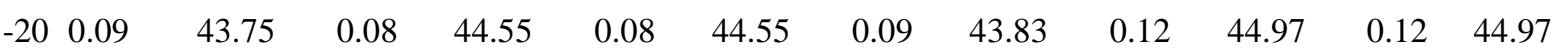

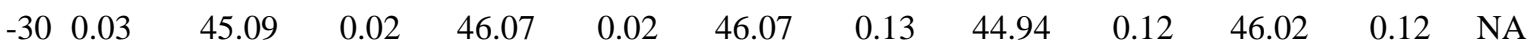

LGT

$\begin{array}{lllllllllllll}0 & 0.61 & 17.44 & 0.56 & 17.30 & 0.56 & 17.34 & 0.61 & 17.44 & 0.56 & 17.30 & 0.56 & 17.34\end{array}$

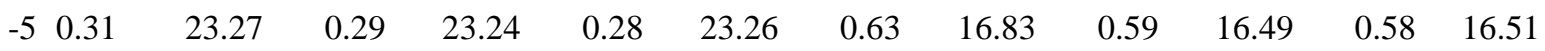

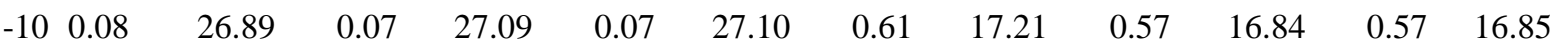

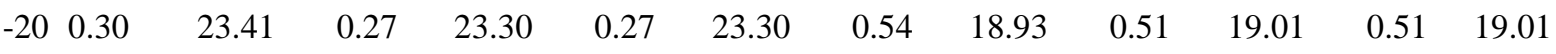

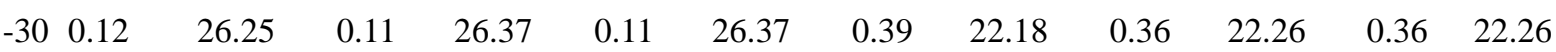




\section{List of figures}

Figure 1: Scheme of the synchronisation process between ER and temperature measurements at different depths $(0$ to $-30 \mathrm{~cm})$. For each site and temperature measurement depth the time series are shifted with 10 minutes steps until a 24 hour shift. The correlation coefficient (R) is used to select the synchronised datasets.

Figure 2: Ecosystem Respiration (ER), air and peat temperature, in the 4 sites (Bernadouze: BDZ, Frasne: FRN, Landemarais: LDM, La Guette: LGT). All data points from all replicates are shown.

Figure 2: Time delay between temperature at different depths and ER, in the 4 sites (Bernadouze: BDZ, Frasne: FRN, Landemarais: LDM, La Guette: LGT).

Figure 4: Profile of $\mathrm{R}^{2}$ and NRMSE, (RMSE, normalized by the mean), with depth, in the 4 sites (Bernadouze: BDZ, Frasne: FRN, Landemarais: LDM, La Guette: LGT) using the exponential model.

Figure 5: Profile of $\mathrm{Q}_{10}$ with depth for synchronised (white) and non synchronised (black) data and exponential model in the 4 sites (Bernadouze: BDZ, Frasne: FRN, Landemarais: LDM, La Guette: LGT). The inset display the same datas but with their full range extend. 
ER time serie

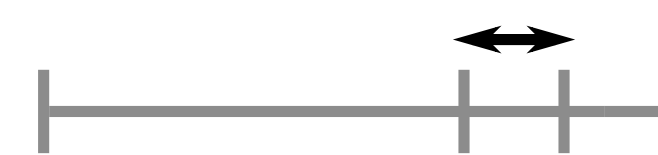

time Temperature time serie
at depth $\mathbf{Z}$
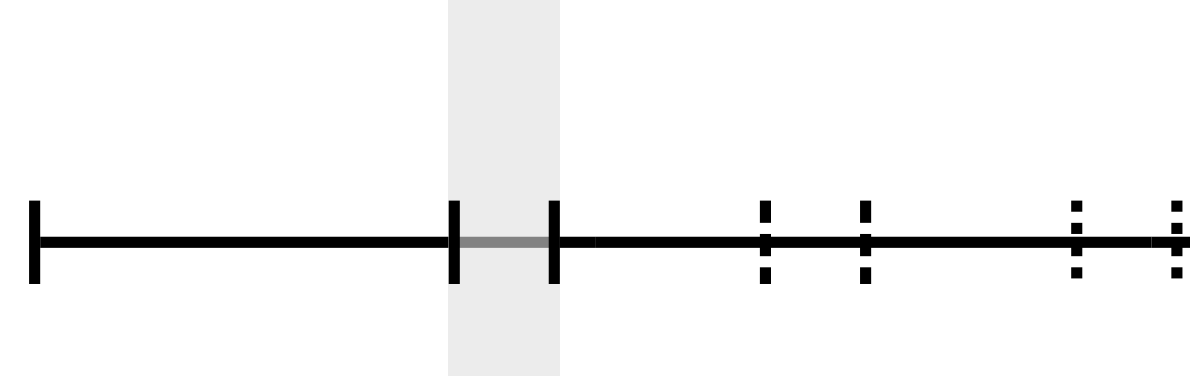

shift: $0 \mathrm{~min}$

$\longrightarrow$

$R=0.7$

$\mathrm{T}_{\text {sync }} 1$ at depth $\mathrm{Z}$

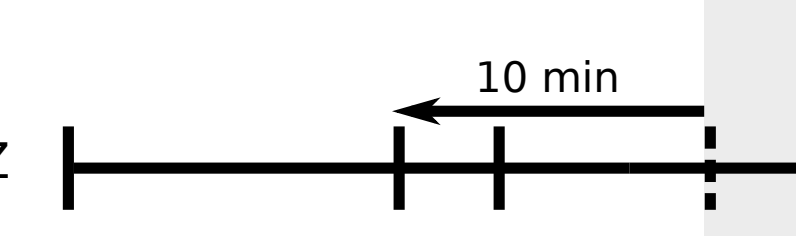

shift: $10 \mathrm{~min}$

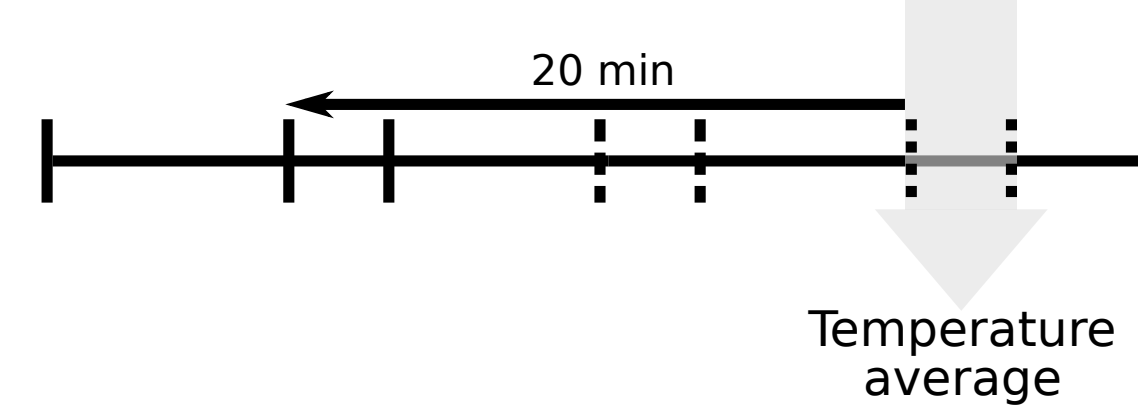

shift: 24 hours

shift: $20 \mathrm{~min}$

$\mathrm{T}_{\text {sync }} 2$ at depth $\mathrm{Z}$ average 

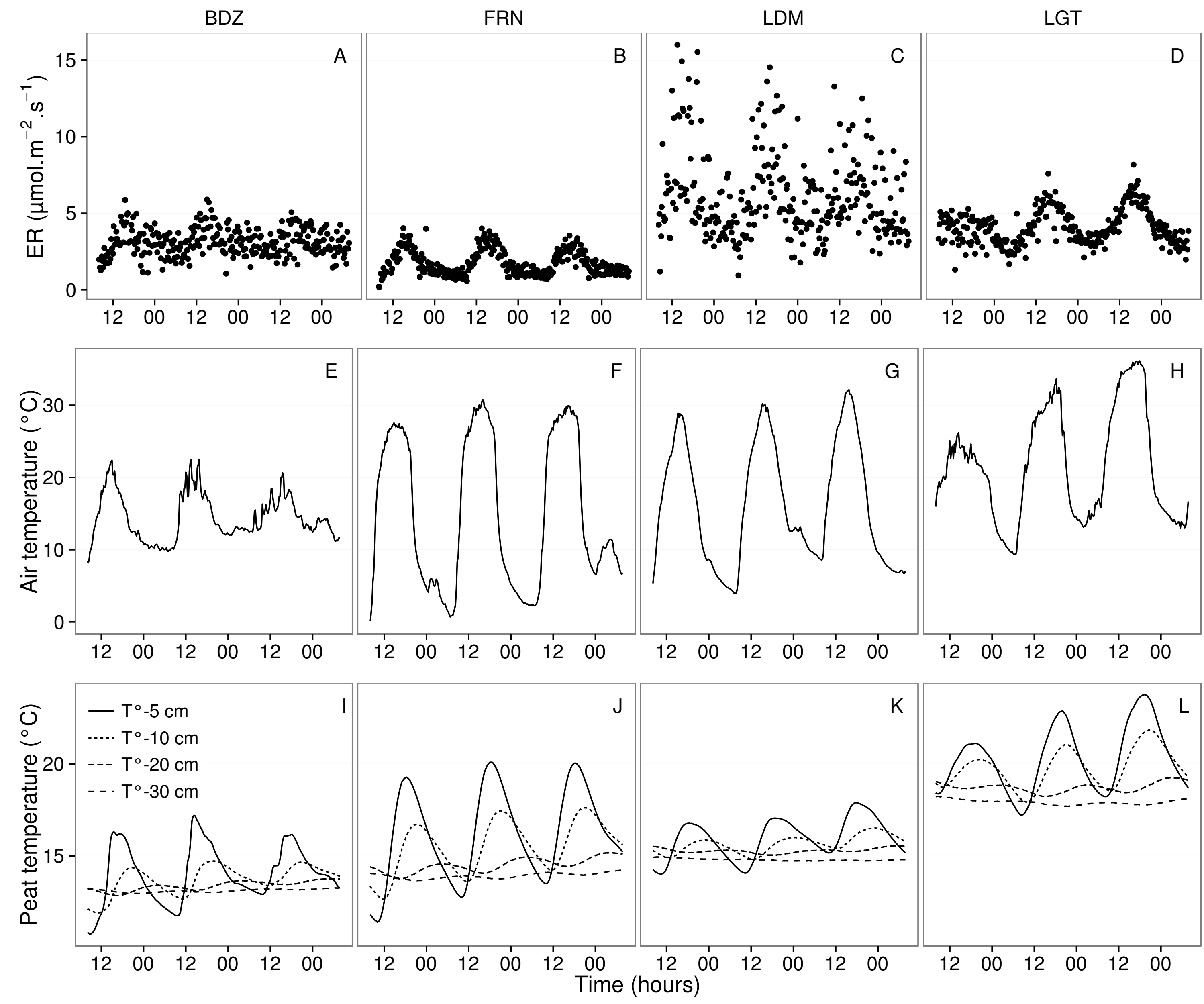


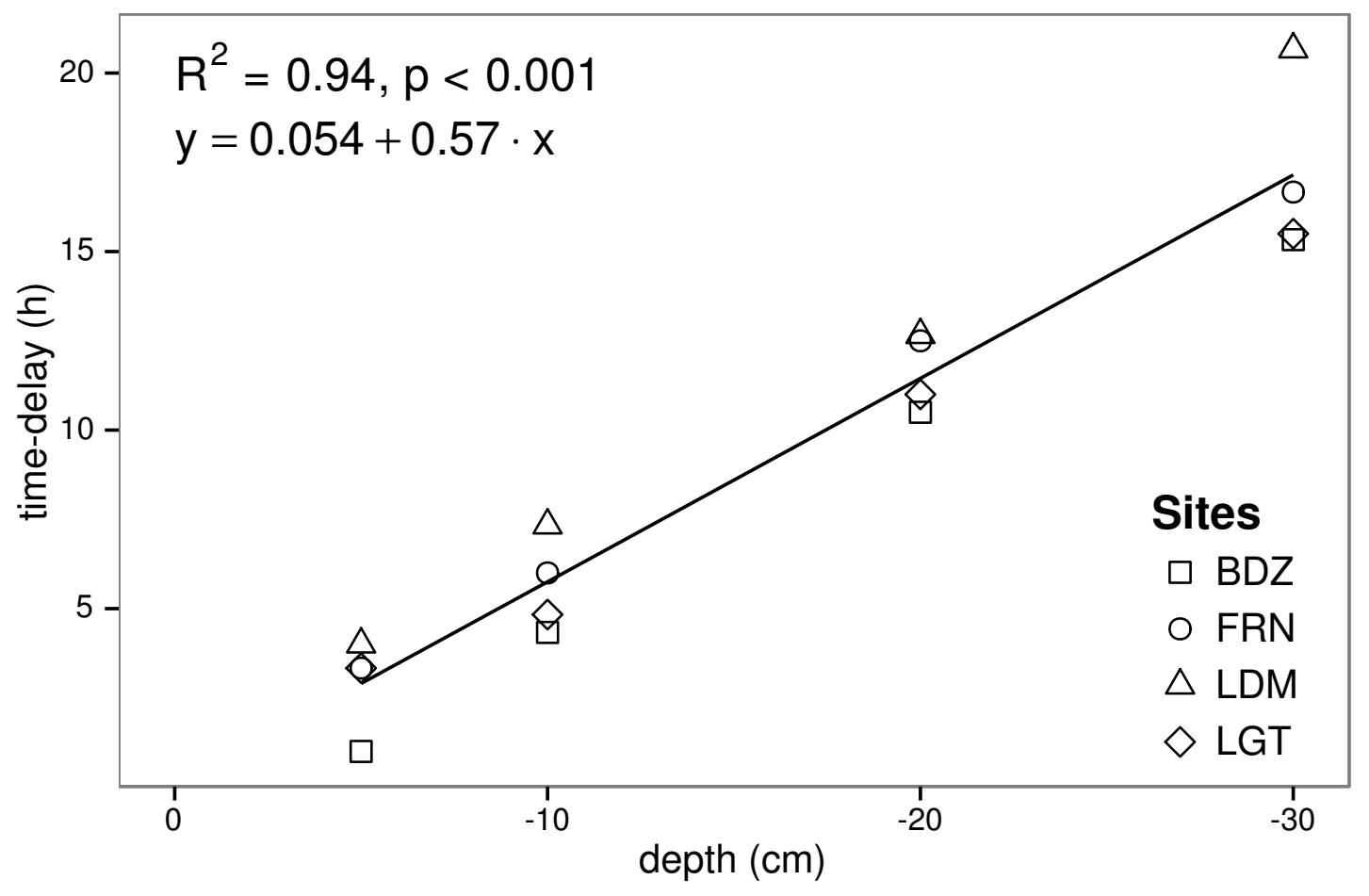




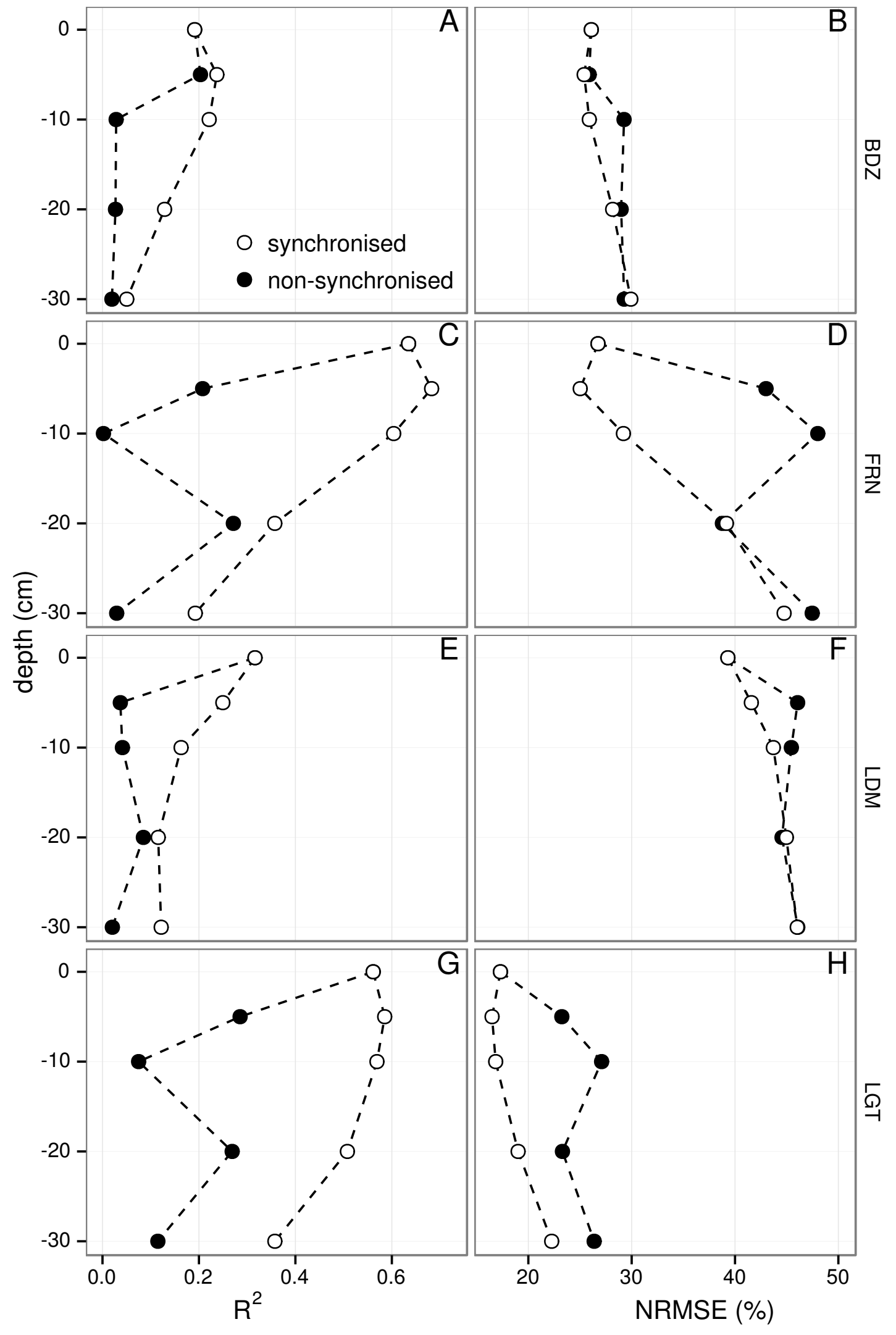




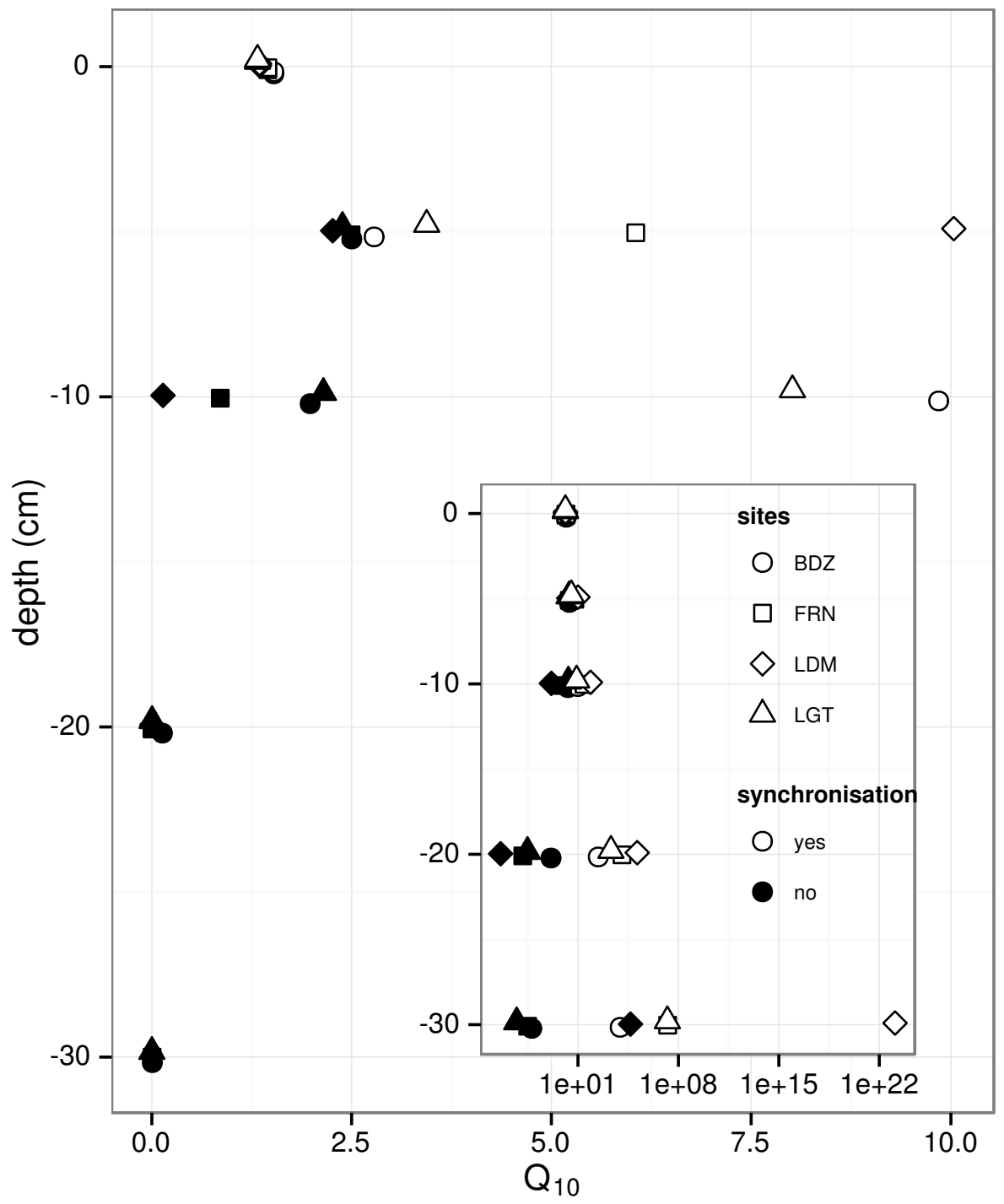

